\title{
Zimbabwean Stakeholder Perceptive of How Mandatory Audit Firm Rotation Contribute to Audit Quality
}

\author{
Olubukola Adegbola Otekunrin ${ }^{1,2, *}$, Kudzanai Matowanyika ${ }^{3}$ \\ ${ }^{1}$ Department of Accounting \& Finance, Landmark University, Nigeria \\ ${ }^{2}$ Landmark University SDG 8 (Decent Work and Economic Growth Group), Nigeria \\ ${ }^{3}$ Graduate Business School, Chinhoyi University of Technology, Chinhoyi, Zimbabwe
}

Received March 8, 2021; Revised May 20, 2021; Accepted June 6, 2021

\section{Cite This Paper in the following Citation Styles}

(a): [1] Olubukola Adegbola Otekunrin, Kudzanai Matowanyika, "Zimbabwean Stakeholder Perceptive of How Mandatory Audit Firm Rotation Contribute to Audit Quality," Universal Journal of Accounting and Finance, Vol. 9, No. 6, pp. 1342-1354, 2021. DOI: 10.13189/ujaf.2021.090613.

(b): Olubukola Adegbola Otekunrin, Kudzanai Matowanyika (2021). Zimbabwean Stakeholder Perceptive of How Mandatory Audit Firm Rotation Contribute to Audit Quality. Universal Journal of Accounting and Finance, 9(6), 1342-1354. DOI: 10.13189/ujaf.2021.090613.

Copyright@2021 by authors, all rights reserved. Authors agree that this article remains permanently open access under the terms of the Creative Commons Attribution License 4.0 International License

\begin{abstract}
There is a consistent debate in the literature on how mandatory rotation of audit firms (MAFR) contributes to audit quality (AQ). For a reason, some have adopted MAFR while others did not. This study examined MAFR to AQ based on stakeholder perceptions. Theoretical insights were established to explore on existing evidence. A descriptive survey design was carried out with a triangulation approach. Interviews were conducted while at the same time questionnaires were administered to accountants, auditors, investors, and management. A population of 71 listed and audit firms were chosen, of which 29 firms were selected using simple random, systematic and purposive sampling. Correlation and regression analysis were used to examine and interpret the quantitative data. The study's findings indicated that MAFR has a positive relationship with AQ from the linear logistic regression computed; therefore, the null hypothesis is rejected. Meanwhile, having firm audit rotation is compulsory for all listed firms, which increases competition and improves independence and new idea development which ultimately results in improved audit quality. The study, therefore, concludes that MAFR is essential. The study recommends that a further study must be done to address other factors that can enhance AQ constituting $67 \%$ shown by the ANOVA test results.
\end{abstract}

Keywords Mandatory, Rotation, Audit, Quality

\section{Introduction}

Researchers have continued to find out factors behind corporate firms failure and to find an appropriate remedy to forestall numerous accounting as well as auditing scandals involved in such corporate firms failure, and it becomes intense not too long after the downfall big firms like Enron, WorldCom as well as Qwest after the well-known Enron scandal, WorldCom as well as Qwest [45]; [41]; [40]; [42]. It is difficult not to involve accounting firms and audit firms with a contract with such a corporate firm before their downfall [1]; [52]. Part of the factors under consideration is audit firms' involvement in numerous corporate failures and the issues of long term audit contracts. This is how the relationship between MAFR and AQ has now been focussed on by scholar as part finding a remedy to audit firms' involvement in numerous corporate failures. The concept of audit failure in the business environment has attracted great displeasure and questions on the validity of the audit standards and regulations and auditors' professional conduct [29]. In Zimbabwe, audit failure case(s) signs can be traced to corruption cases associated with embezzlement of funds and listed companies with audit tenure of over 30 years. The root of the audit failure has been associated with long term audit contracts which have also been associated with independence threat. Irrespective of the debate, this study's justification lies in the argument that, if the MAFRm is much desired, why should it then be restricted to the 
banking sector alone as questioned by stakeholders? Does it affect audit quality? If developed countries like the USA and UK root for audit firm rotation, why not attempt it? Before we expose ourselves to such consequences, the study sought to investigate the effect of MAFR on AQ by establishing different perceptions regarding the relationship between the two.

\section{Literature Review}

\subsection{Mandatory Audit Firm Rotation\& Its Emergence}

MAFR refers to the enforced switching of audit firm by companies after a predetermined established period [10]. On the other hand, rotation may either be audit firm rotation, which appeals for publicly listed companies to alter or rotate their lead contracted audit partner after a specific period or lead audit change after a regulated period ([3], [39]). Although there is also voluntary Audit Firm rotation, the focus of this study is MAFR. Auditor rotation principle was initially introduced and discussed three decades ago. The idea was brought during a Congress in 1977 after numerous financial corporate scandals, which created confusion amongst stakeholder groups regarding auditors' performance. Moreover, MAFR attracted criticism within the committee which had been delegated to deal with the issue [6]. The intensity of the matter rose and finally gave birth to the Sarbanes-Oxley (SOX), but was prohibited after [13]. Hence, regulators, policy makers, and architects over the globe began to deliberate on the implementation of the rule [22[. In August 2011, following a decade of the SOX alterations, the most significant accounting board Public Companies Accounting Oversight Board (PCAOB) considered that reconsidering audit firms' rotation was still an issue to debate citing the reasons surrounding auditor's existence. Compulsory audit rotation enactment came into practice to increase transparency and confidence and enhance AQ ([51]). One of the reasons for rejection was the political influence and not based on facts.

\subsection{Concept of Audit Quality}

There are specific fundamental characteristics to lookout when AQ focuses on the discussion of which the study adopts. An AQ must be reliable, significant, objective, transparent, timely, effective, and efficient [55]. Yuniarti [53] contends that the combination of these features as a whole gives quality to the audit. This indicates that AQ is noticeable where these characteristics can be identified. The credibility of financial statements is affected by these factors. However, to undertake the study, the researcher intends to measure AQ by looking at the basic principles that an audit process must present as accorded by [55] and the auditor and stakeholders' opinion.

\subsection{Some Arguments for Mandatory Audit Firm Rotation on Audit Quality}

Firstly regulated duration of any client engagement decreases the pressure of monetary and other benefits to risk auditor's independence. As a result, auditors may be prepared to challenge management on creative accounting and other financial reporting issues. Wilson, McNellis, and Latham [53] claim that rotation assists in decreasing self-interest bias in which auditors would make decisions in favour of their interest, as desires may no longer be fully aligned. Due to time influence, audit members might start to recognize themselves as part of the client team consistently, and that can influence the auditor's freedom in assessing the transparency, accuracy, and reliability of the clients' accounts, thus manipulating interpretation of facts. ([37]; [14]) Secondly, unrestricted audits result in the audit firm's personnel becoming too familiar with the company whose records they are meant to review objectively, honestly and accurately. This implies that with the existence of period restriction connection between auditors and clients increase the level of freedom and conflict of interest is minimized. Thirdly audit as a broad concept built on trust, shareholders believe in the appointed auditor's ability to generate fresh ideas on the management activities [7]. Kim, Kim, Lee, \& Yoo (2019) opined that audit firm rotation facilitates new idea development and moderation. When a particular audit firm carries out the same duty for a continuous period, it may plunge into a kind of professional routine.

\subsection{Some Arguments against Mandatory Audit Firm Rotation on Audit Quality}

Audit firms are just like any other firms and their services attract a cost which has to be expensed. Audit firm changes increase switching and start-up cost to both the auditors and the clients on the end of it, the auditor would have to increase audit fees to absorb the cost to be incurred at the end of the engagement [11]. Secondly, adversaries of audit firm rotation argue that audit firms' compulsory switching intensified start-up expenditures and increased the risk of audit failure. New auditors have to depend on client management approximations, evaluation and estimates; therefore independent representation in the initial years of an audit engagement is now thus AQ would be low [33]. Thirdly compulsory periodical audit firm switching has consequences of losing client-specific knowledge possessed by the audit firm. That means the new auditor needs a sufficient amount of time (the learning curve) to become familiar with the clients' accounting systems, internal controls, reporting structures and only a few to mention ([48]).

\subsection{Stakeholder Perceptions Regarding Mandatory Audit Firm Rotation}

\subsubsection{Accounting Firms}

PwC responded against the rule citing a lot of irregularities. PwC audit firm thought that the audit firm's 
compulsory rotation does not increase auditor independence or enhance audit quality. In their opinion, there is no empirical evidence that it does and it does not improve market concentration. Their argument indicated that MAFR had been implemented and repealed in many other markets such as New Zealand, Singapore, due to not achieving on these objectives and having unintended consequences, including having counter effects than intended. Other firms in support of PwC included KPMG and Ernst \& Young. They all argued against compulsory firm switching.

\subsubsection{Government and Regulatory Bodies}

The imposition of audit firm rotation has been debated by many countries of which some have adopted it, and various regulatory bodies attempted to implement it by passing on several guidelines. In the US PCAOB enacted the rule referred to as the Sarbanes-Oxley Act or SOX). The Act's provisions limit the lead audit partner to audit the client firm not longer than five years [8]. In Korea, the regulating board titled Korean Financial Supervisory Services (KFSS) in 2006 proposed and mandated audit firm rotation, which required audit firms to be rotated every seven years, and the policy is still in motion. Successively, the European countries perceive the rule of firm audit rotation to reduce auditor-auditee relationship. South Africa imposed the principle of firm audit rotation as a countermeasure to increase independence and improved quality of information. However, Zimbabwe, the market regulator in Zimbabwe Stock Exchange, proposed that MAFR be listed as part requisite for all firms listed on stock exchanges, but this has not been implemented in other sectors of the industry that is in state corporations [50].

\subsubsection{Investors}

As a result of continuous audit scandals, investors expressed disappointment about the work of auditors. Auditor's independence has been questioned. From the prior research [19]; [31]; [15] conducted, investors cited the solution to audit failure as being audit firm rotation. Investors perceive MAFR as impacting AQ as it would enhance auditor independence [38].

\subsubsection{Audit Clients}

Kimball International, Inc. [23] asserts that MAFR is perceived in many directions by audit clients. One of their views is that auditors can be biased in favour of management to renew their contract continually. Therefore, they oppose a long-term contract. However, more extended audit engagement is believed to affect the auditor's ability to insistently and honestly open and revive queries about client practices (Stringer, 2011). Audit clients majorly see MAFR from their bias point of views.

\subsection{Ways to enhance Audit Quality}

Many factors can determine audit value despite audit rotation as purported by other researchers as given below:

\subsubsection{Audit Fees}

Audit fees can increase auditor efficiency when performing the client's task if they are commensurate to the task being done [5]. Abdul Rahman \& Hamdan [1] state that the AQ is dependent on the audit fee; the higher the audit fee, the more qualitative and reliable the audit work will be. Audit fees which comprise of audit expenses such as audit tax, auditors travelling cost, cost on time expended auditing a client are signs of economic dependence and may influence auditor independence and consequently poor AQ [18].

\subsubsection{Provision of Other Services}

Meckfessel and Sellers [29] claim that consulting level size has a constructive significant statistical effect on audit reporting and restatement rate. When an accounting firm has a huge consulting practice size, it ultimately leads to decreased attention on auditing services, consequently contributing to decreasing audit quality. In another observation, it is reported that most of the companies involved in the accounting scandals were paying large non-audit services to their auditors. This created serious doubts regarding the appearance of auditor independence and jeopardized the credibility of financial statements.

\subsubsection{Auditor Reputation}

DeAngelo [12], asserts that stakeholders use auditor reputation on financial statements to infer unobserved quality audit based on the provided audit reports. Audit firm constructs its reputation over a period of time by generating quality work. To uphold this reputation, total commitment is ensured on every member of the audit team and other professionals within since a well-earned status should conform to the report presented in each audit report [24].

\subsubsection{Auditor Competence and Professional Due Care}

The code of professional ethics mandates auditors to exercise professional due care and competent in executing their duties regarding audit work as they are supposed to communicate their findings with another third part (economic users). According to IAASB, AQ is a process founded on such matters as the efficacy of audit tools applied, the reliability of the audit approach used, and sufficient technical backup all headed for supporting the execution of the quality audit. Meanwhile, competence is regarded as an audit tool that determines the methodology of the auditor's audit and capability to realize a matter of concern during the audit process.

\subsubsection{Auditor Independence}

An auditor is independent when he/she is not bias or influence when carrying out his/her duty. The auditor may fail to represent facts as facts due to some factors which 
include familiarity with the client, which would affect the AQ. Audit independence is a factor which can enhance AQ if considered with high caution [35]; [36]. An auditor's ability to recognize the code of ethics and act without influence can result in audit satisfactory.

\subsubsection{Proper Audit Committee Members}

AQ is obtained by identifying and administering the activities needed to achieve the quality objectives of an organization. Since an entity's internal control is under the purview of its audit committee, it is crucial in enhancing AQ [45; [2]. The effectiveness of audit committee is subject to the degree to which the committee is capable of resolving issues and complications the company faces and to improve their monitoring function of company activities [21].

\subsubsection{Industry Specialization}

Industry specialization refers to the extent to which auditors have previously attended to issues about the certain industry before, which might reflect his ability to understand aspects of such an industry or area [46].The relationship between $\mathrm{AQ}$ and auditor industry expertise or specialization has been extensively examined in prior research and has been observed that there is both a positive and negative relationship.

\subsubsection{Audit Firm Size}

Large audit firms have many clients; therefore, failing to observe material distortions will cause more loss to large audit firms. Perhaps, large firms are financially stronger, and their employees are technologically capable of finding material misstatements. Audit firm size can represent the auditor's capability to provide a reliable and blended opinion which significantly means AQ is enhanced [25].

\subsection{Previous Studies on Mandatory Audit Firm Rotation}

Harris and Whisenant [17] investigated whether MAFR set of laws and variations in the AQ markets are directly associated. Their result established that the sampling era after implementation of MAFR rules, the data revealed proof of more prudence and fewer earnings management against the sampling era before the implementation of MAFR. The research established that the AQ markets improved, on average, ever since audit firm rotation was enacted. Siregar, Amarullah, Wibowo, and Anggraita [48] also arrived at similar results in their study. The results do not support that MAFR improves the AQ or that a shorter audit mandate increases the AQ. Chi, Huang, Liao and Xie [9[ observed the statutory audit rotation's effectiveness by promoting AQ in Taiwan. The study found some evidence that the AQ carried out in 2004 by the firms under MAFR was greater than the AQ of non-rotated companies.

\subsection{Theoretical Underpinnings of the Study}

\subsubsection{The Agency Theory}

An agency relationship is an indenture under which one or more persons (the principal(s) appoint another person (the agent) to accomplish some service on their (principals) behalf which involves assigning some decision-making authority to the agent [20]; [43]. The circumstances in which the interest of the principals and agents conflict shows the possibility that agent (management) did not act in the best interest of the principals (shareholder). However, managers can take advantage of the confidential, accessible information to trade in the entity for their interest, and this behaviour leads to agency conflict. Therefore the quality of information reported might be there to mislead the principal. Meanwhile, auditors are meant to clear the air and suspicions of misconduct and instil confidence in shareholders (owners) [4]. In an endeavour, by the principal to monitor and be able to ascertain whether the agents are acting on his or her behalf they have chosen to appoint responsible parties who will also act on their behalf by assessing the agents' actions on the wealth of the principal which in this case are called auditors. Auditors when called in they are contracted as watchdogs, not blood hunters. Therefore, since auditors are engaged as agents under contract they are expected to be independent to the management, of which in some cases they might fail to and thus the request to rotate them. It is for this reason agency is adopted in this study.

\subsubsection{Theory of Inspired Confidence}

Inspired Confidence theory identifies auditor, as a confidential, independent agent, whose function is derived from the need for expertise and independent judgemental assessment plus the need for an outside expert and independent judgment supported by facts and proper evidence [44]. To reduce the threat of undetected misstatements, the theory implies that an auditor must execute audit work in a manner that does not let down the users' confidence [34]. The quality of work produced must be able to meet the expectation of the public greatly. Auditor has to supply information that gives assurance to enhance confidence in stakeholders. Limperg states that divergence from the principles and responsibilities can cause their need to be rotated or changed to maintain confidence in shareholders. For a reason, that information given by the management might be biased according to the Agency Theory and Contracting Theory. In other words, in a "Principle-Agent" relationship, there is always an information asymmetry between the firm and the shareholder. 

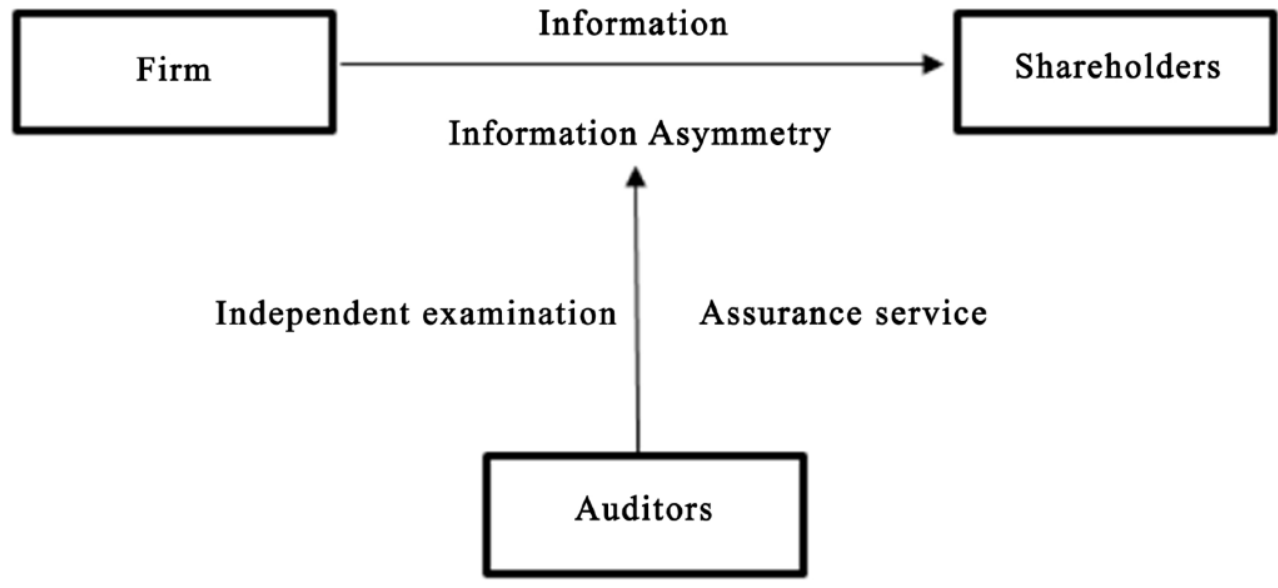

Source:[27].

Figure 2.1. The role of the auditor in installing confidence and assurance

\subsubsection{The Information Theory}

Information theory emanates on the perspective that auditors are there to provide and communicate information about the organization's financial matters.

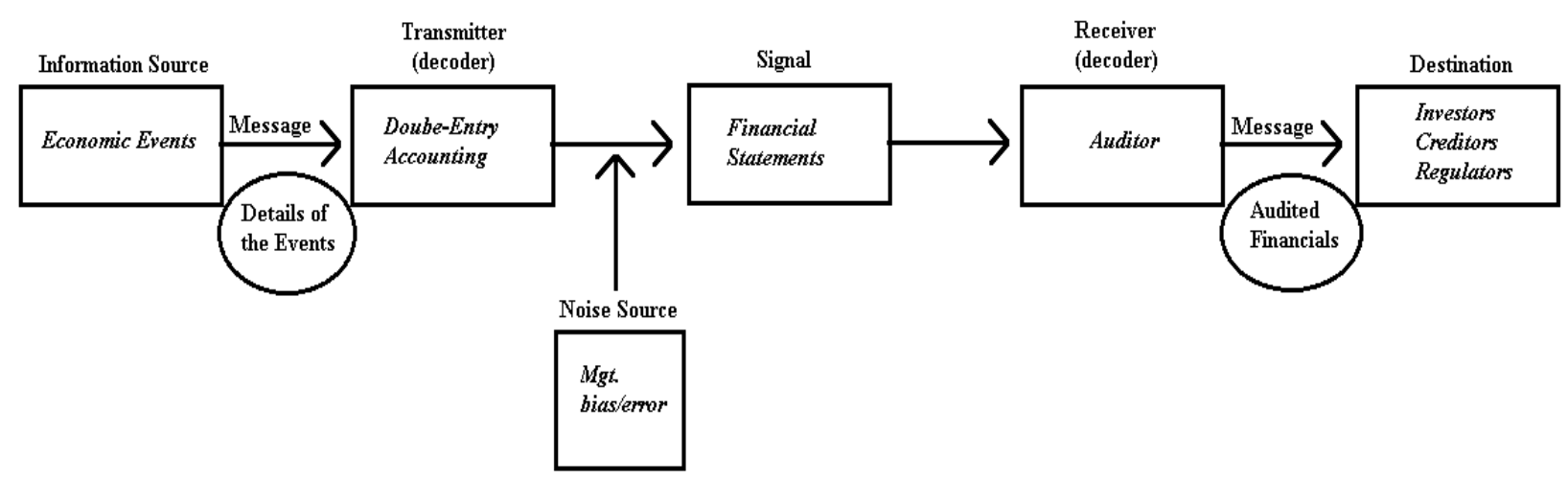

Figure 2.2. Accounting as a communication system

This figure displays how Auditor fits into the classical framework of an information system. The theory suggests that auditors conduct must not hinder their ability to communicate information that is sufficient enough for use by economic users which are investors, creditors, regulators and any other as presented in Figure 2.2. In Europe, MAFR has been recognized to recover the perception of auditors and the usefulness of financial reports and reduce information risk.

\subsubsection{Institutional Theory}

Institutional theory endeavours to careful observe aspects of social structure in addressing a specific area of discussion. It cogitates the procedures by which structures, together with rules, norms, routines, and schemes; turn into established authoritative rules for public social behaviour. Institutions advocate a regulation such as the ZSE proposal to make the MAFR protect the interests of interested parties. A highly institutionalized area puts pressure on regulatory structures and regulators due to the state's power and other external forces that influence regulatory structures to adopt practices that meet expectations. South Africa Independent Regulatory Board for Auditors (IRBA) and PCAOB in the USA are part of their countries regulatory structures and regulators handling MAFR issues in their respective countries.

\subsection{Development of Hypotheses}

The literature review debate on MAFR contributions to AQ continues to be a contentious matter among stakeholders. For this reason, MAFR has adopted by countries (e.g. South Africa, Argentina, Brazil, China, Italy, India, and South Korea) some countries (e.g. Nigeria) on still debating it. In contrast, some other countries (e.g. Hongkong, Japan, Malaysia, Philippines) did not adopt it. We carry out this study as a part empirical examination of MAFR contributions to AQ to further strengthen the body of knowledge in accounting and audit practice on the subject matter. Hence, the null hypothesis tested in this research is stated below:

$\mathrm{H}_{0}$ : Audit firm rotation has no significant effect on audit quality 


\section{Methodology}

The researcher used descriptive research design to establish the relationship between audit firm rotation and audit quality. Data were obtained from audit firms, public listed companies, government and investors on their opinion on the different quality parameters. The Zimbabwe Stock Exchange represented government and investors. Descriptive survey research was chosen as a reliable measure because AQ perceptions and understanding vary from person to person's view: interviews and questionnaires. For the study, the researcher used both qualitative and quantitative approach. The study population comprised the 71 companies both accounting firms and active companies listed on Zimbabwe Stock Exchange and Government and investors represented by Zimbabwe Stock Exchange. The sample size consisted of 29 companies from those in the population. Law [26] underlined that a sample size of $30 \%$ of the population could fairly represent the population and therefore $30 \%$ of the population, in this case, would be 23 firms. Therefore, 29 out of 71 respondents $(40.8 \%)$ were used, which is slightly higher than that supported by [26].
Table 3.1. Sample

\begin{tabular}{|c|c|c|c|}
\hline Type of firm(s) & Population & Sample & $\begin{array}{l}\text { Sampling } \\
\text { Technique }\end{array}$ \\
\hline Listed Companies & 60 & 18 & $\begin{array}{l}\text { Stratified, } \\
\text { Purposive and } \\
\text { Simple Random }\end{array}$ \\
\hline $\begin{array}{l}\text { Accounting } \\
\text { firms(registered) }\end{array}$ & 10 & 10 & Simple Random \\
\hline $\begin{array}{l}\text { Government and } \\
\text { Investors } \\
\text { (Zimbabwe Stock } \\
\text { Exchange) }\end{array}$ & 1 & 1 & Purposive \\
\hline Total & 71 & 29 & \\
\hline
\end{tabular}

The total sample institutes all 10 Accounting firms in the population to represent the group. The researcher chose the whole ten firms to represent the population since it was too small to sample. The ten audit firms were registered by PCAOB and internationally recognized on the Zimbabwe Stock Exchange database. Moreover, 18 listed companies that require the services of Accounting firms and Government represented by the Zimbabwe Stock Exchange were chosen.

Table 3.2. Distribution of Research Instruments.

\begin{tabular}{|c|c|c|c|c|}
\hline & $\begin{array}{l}\text { Listed } \\
\text { companies }\end{array}$ & $\begin{array}{l}\text { Accounting } \\
\text { firms }\end{array}$ & $\begin{array}{l}\text { Government\& } \\
\text { Investors(ZSE) }\end{array}$ & \\
\hline Sample & 18 & 10 & 1 & \\
\hline Management & 18 & 10 & 3 & Interviews \\
\hline Accountancy & 36 & 20 & & Questionnaires \\
\hline Auditors & 36 & 20 & & Questionnaires \\
\hline
\end{tabular}


We chose to group the population in strati depending on industry sector of companies such as banking, manufacturing etc. hence simple random sampling was then applied. Each company chosen to represent the sample 1 respondent from each department (Audit and Accounting) was given the questionnaire, and the Manager was interviewed. Stratified, purposive (judgmental or subjective or selective) and simple random sampling was used to identify characteristics of a population of interest to answering the research questions and stakeholders such as investors and government, Zimbabwe Stock Exchange was chosen. When choosing a sample to represent the population, the following characteristics and assumptions were used: PCAOB registers audit firms, both audit firms and listed companies are well-versed with the concept of audit quality, the period of listing on the stock exchange and firms newly listed in 2018 were not considered for the sample. However, they were part of the population. The justification for their exclusion was they have not yet gained enough experience and exposure. Primary tools were questionnaires, observations and personal interviews. The questionnaire was in the form of Likert scale, open-ended questions and closed questions. The open-ended questions enhanced the opportunity to gather rich and in-depth information as respondents were at liberty to express their feelings and experiences. The questionnaire was designed from the research questions, and other previous journals were modified and used for this research. The researcher interviewed the managers and audit team and observations and formed part of the techniques used to gather the information that could not be expressed through word of mouth and questionnaires during interviews. Secondary data was acquired from textbooks, financial reports, the internet, newspapers, magazines and Audit firms' newsletters. In an attempt to ensure the validity of the collected information, a pilot study was conducted to determine the instrument's reliability. The semi-structured questionnaire was administered to 5 users from the sample. The responses from the semi-structured questionnaire were coded, and reliability was determined, and interviews were conducted. The instruments were given to the experts at different companies, after their analysis and comments, necessary adjustments and modifications were made. However, regression and correlation were used to establish the reliability of the data collected.

\section{Data Presentation and Analysis}

\subsection{Response Rate}

The researcher used a set of research instruments to gather data specifically for the study, which are questionnaires and interviews and secondary data sources.
Table 4.1. Overall response rate for subjects conducted in the fieldwork

\begin{tabular}{|c|c|c|c|}
\hline Respondents & $\begin{array}{l}\text { Sample } \\
\text { conducted }\end{array}$ & $\begin{array}{l}\text { Responses } \\
\text { returned }\end{array}$ & $\begin{array}{l}\text { Response } \\
\text { Rate (\%) }\end{array}$ \\
\hline \multicolumn{4}{|l|}{ Questionnaires } \\
\hline $\begin{array}{l}\text { Accounting } \\
\text { Department }\end{array}$ & 56 & 46 & 82 \\
\hline Audit Department & 56 & 43 & 76.7 \\
\hline Total Questionnaires & 112 & 89 & 79.5 \\
\hline \multicolumn{4}{|l|}{ Interviews } \\
\hline Management & 29 & 21 & 72.4 \\
\hline $\begin{array}{l}\text { Overall response for all } \\
\text { sample objects }\end{array}$ & 141 & 110 & 78 \\
\hline
\end{tabular}

As demonstrated by the table, the overall response rate of the respondents was 78\%. Questionnaires administered to accounting and audit departments for those organizations in the sample were 112 , and 89 of them were obtained back which means a total of 23 were not returned thereby reducing the number of questionnaires to be used (20.5\% failure). Of the 29 managers, only 21 were conducted for interviews since they were available and convenient to participate, and it makes a $72.4 \%$ response rate. To supplement the collection of data, the researcher, at times referred to the interview guide. The overall response rate is $78 \%$ which is satisfactory and acceptable as supported by Dillman (2000), who alluded that a response rate of $70 \%$ is highly acceptable. Therefore, $78 \%$ attained from this survey is adequate to generalize the results for the study population.

\subsection{Demographics}

\subsubsection{Participants Gender}

Table 4.2. Gender for returned questionnaires\& Interviews conducted

\begin{tabular}{lll}
\hline Indicator & Frequency & Percent \\
Male & 10 & 47.6 \\
Female & 11 & 52.4 \\
Total & $\mathbf{2 3}$ & $\mathbf{1 0 0 . 0}$ \\
\hline
\end{tabular}

Source: The Research Survey (2018)

Table 4.2 shows $52.8 \%$ male \& $47.2 \%$ females for returned questionnaires and interview.

\subsubsection{Respondents' Age}

Table 4.3. Respondents' age

\begin{tabular}{ll}
\hline Age & \% \\
\hline Less than 25 & 15.7 \\
$26-35$ & 29.2 \\
$36-45$ & 27 \\
$46-55$ & 19.1 \\
56 and above & 7.0 \\
& 100 \\
\hline
\end{tabular}

Source: The Research Survey (2018)

The age distribution of respondents shows 25 years and below consisted of $15.7 \%$ of the total respondents, 26- 35 years $(29.2 \%), 36-45(27 \%), 46-55$ years $(19.1 \%), 56$ years and above category comprising of $7 \%$. 


\subsubsection{Respondents' Qualifications}

Table 4.4. Respondents Qualifications

\begin{tabular}{ll}
\hline & $\%$ \\
\hline Diploma & 9 \\
First Degree & 50.6 \\
Master Degree & 33.7 \\
Professional & 6.7 \\
& 100 \\
\hline
\end{tabular}

Source: The Research Survey (2018)

The education distribution level shows first degrees (50.6\%), first degrees (33.7\%). Diplomas (9\%) and 6.7\% professional.

\subsubsection{Experience}

Table 4.4: shows experiences of respondents, less than one year were $(6.74 \%$,$) 2-4 years (17.98 \%), 5-8$ years $(32.58 \%)$, and nine years and above (42.7).
Table 4.4. Respondents' Experiences

\begin{tabular}{ll}
\hline Years & \% \\
\hline Less than one & 6.74 \\
Two to four & 17.98 \\
Five to eight & 32.58 \\
Nine and above & 42.7 \\
& 100 \\
\hline
\end{tabular}

Source: The Research Survey (2018)

\subsection{Reliability and Validity}

\subsubsection{Correlation Matrix}

The examination using Pearson's correlation analysis was centred on the notion that data in the study is normally distributed as well as the continuous variable. Correlation tests exemplify the degree one variable relates to another alternative variable and ranges from -1 (perfect negative correlation and +1 (perfect positive correlation). A correlation value of 0 or near zero means there is no relationship between the two variables. A correlation test was done and presented as follows.

Table 4.5. Correlation co-efficient factor analysis

\begin{tabular}{|c|c|c|c|c|c|c|c|c|}
\hline & & $\begin{array}{l}\text { audit } \\
\text { quality }\end{array}$ & $\begin{array}{l}\text { audit firm } \\
\text { rotation }\end{array}$ & $\begin{array}{l}\text { audit } \\
\text { fees }\end{array}$ & $\begin{array}{l}\text { Non-audit } \\
\text { service }\end{array}$ & $\begin{array}{l}\text { audit } \\
\text { committee }\end{array}$ & $\begin{array}{l}\text { Audit } \\
\text { independence }\end{array}$ & $\begin{array}{l}\text { Board } \\
\text { size }\end{array}$ \\
\hline \multirow{2}{*}{ audit quality } & P-Correlation & 1 & & & & & & \\
\hline & Sig. (2-tailed) & & & & & & & \\
\hline \multirow{2}{*}{$\begin{array}{l}\text { Audit Firm } \\
\text { rotation }\end{array}$} & P-Correlation & .106 & 1 & & & & & \\
\hline & Sig. (2-tailed) & .020 & & & & & & \\
\hline \multirow{2}{*}{ audit fees } & P-Correlation & .083 & .254 & 1 & & & & \\
\hline & Sig. (2-tailed) & .069 & .140 & & & & & \\
\hline \multirow{2}{*}{ Consultancy } & P-Correlation & -.086 & .232 & -.055 & 1 & & & \\
\hline & Sig. (2-tailed) & .340 & .161 & .702 & & & & \\
\hline \multirow{2}{*}{ audit committee } & P-Correlation & .042 & .016 & .063 & .126 & 1 & & \\
\hline & Sig. (2-tailed) & .002 & .043 & .035 & .045 & & & \\
\hline \multirow{2}{*}{$\begin{array}{l}\text { Audit } \\
\text { independence }\end{array}$} & P-Correlation & .145 & .110 & -.184 & .145 & .485 & 1 & \\
\hline & Sig. (2-tailed) & .285 & .464 & .191 & .283 & .000 & & \\
\hline \multirow{2}{*}{ Board size } & P-Correlation & .080 & -.020 & -.142 & -.088 & .468 & .358 & 1 \\
\hline & Sig. (2-tailed) & .094 & .009 & .011 & .0 .043 & .000 & .001 & \\
\hline Level of signific & t 0.05 level. & & & & & & & \\
\hline
\end{tabular}


Table 4.5 illustrates the correlation test conducted in relation to the variables chosen for the test. Meanwhile, the variables were designed into distinct variables by determining the arithmetic mean of firm audit rotation, audit fees, consultancy services (non-audit services), audit committee, audit independence, and board size information. Pearson's correlation analysis was positioned at $95 \%$ and $5 \%$ confidence interval 2-tailed level. As per findings from the table 4.5, there exists a weak positive correlation between audit firm rotation and AQ as exposed by the coefficient of 0.106 , a positive relationship amongst AQ and audit fees as articulated by a coefficient of 0.083 , a strong negative correlation between $\mathrm{AQ}$ and audit consultancy services as shown by coefficient -0.086 , This indicates that the audit firm rotation is significant $0.020<0.05$ sig-level though not strong, however, consultancy services failed to prove the effect gaining a negative score and the level of significance fell above 0.05 that is insignificant. Audit committee shows a weak positive relationship as the 0.042 was getting closer to 0 ; the level of significance was below the accepted 0.05, which indicates that it is significant. Audit independence and AQ positive related to a correlation of 0.145 , which reflects the relationship is weak. More so, board size has a significant relationship with $\mathrm{AQ}$, which is 0.080 (2-tailed). Unfortunately, audit firm rotation, audit fees, audit committee, audit independence, and board size gave a positive correlation magnitude while consultancy scored a slightly lower and weak. This means that all other factors tested have a positive influence on AQ as compared to consultancy. Moreover, AQ is positively influenced by audit firm rotation, audit fees, audit committee and board size with a significantly lower effect. Still, the other proportion remains to other factors not mentioned. These results are consistent with the survey study findings of [22] on suggestions that audit firm rotation produces better AQ when it exists.

\subsection{Regression Analysis and Hypothesis Testing}

The researcher establishes the connection between AQ and other variables (audit firm rotation, audit fees, consultancy services, audit committee, audit independence and board independence)

$$
\boldsymbol{Y}=\propto+\underset{\in}{\propto} \beta_{1} X_{1}+\underset{2}{\beta_{2} X_{2}}+\beta_{3} X_{3}+\beta_{4} X_{4}+X_{5} X_{5}+\beta_{6} \beta_{6}+
$$

Where:

$\mathrm{Y}=\mathrm{AQ}$ as measured by the overall rating of an audit by accountants and auditors= Audit Quality as measured by an overall rating of an audit by accountants and auditors

$\mathrm{X}_{1}=$ Audit rotation, as measured by the audit engagement period in the last five years.

$\mathrm{X}_{2}=$ Consultancy services provided other than audit services as measured by management opinion on other services.

$\mathrm{X}_{3}=$ Audit fees as measured by the audit client rating on the audit fees

$\mathrm{X}_{4}=$ Opinion by accountants and auditors on Audit committee towards quality.

$\mathrm{X}_{5}=$ Opinion by accountants and auditors on board size effect on audit quality

$\alpha=$ Regression constant

$\mathrm{X}_{6}=$ Audit independence

$\epsilon=$ Error term

Table 4.6. Model summary of regression analysis

\begin{tabular}{lllll}
\hline Model & R & R Square & Adjusted R Square & Std. Error of the Estimate \\
\hline 1 & .5 & .328 & 116 & 1.089 \\
\hline
\end{tabular}

Meanwhile, the adjusted $R^{2}$ was applied to indicate the explanatory extrapolative power of the study model. Furthermore, it is found to be 0.328 entailing that $32.8 \%$ of the AQ disparities are explained by audit firm rotation, audit fees, consultancy services, audit committee, the board size, and audit independence, leaving $67.2 \%$ percent unexplained which is quite a huge proportion left out.

Table 4.7. ANOVA Results

\begin{tabular}{ccllll}
\hline Model & Sum of Squares & Df & Mean Square & F & Sig. \\
\hline 1 Regression & 11.012 & 6 & 1.835 & 1.548 & .031 \\
Residual & 22.526 & 19 & 1.186 & & \\
Total & 33.538 & 25 & & & \\
\hline
\end{tabular}

In predicting the influence of Audit firm rotation as a control variable in the study, and other support variables on audit quality, the regression model test was significant since p-value was less than 0.05 and The calculated $\mathrm{F}$ (1.548) compared with the critical value of $\mathrm{F}=2.530$ smaller. 
Table 4.8. Regression Co-efficient

\begin{tabular}{cccccc}
\hline Model & \multicolumn{2}{c}{ Unstandardized Coefficients } & $\begin{array}{c}\text { Standard } \\
\text { Coefficients }\end{array}$ & $\boldsymbol{T}$ & Sig \\
\hline & B & Std Error & Beta & & \\
(Constant) & 5.779 & 3.303 & & 1.749 & .096 \\
Audit firm rotation & .087 & .312 & .059 & .278 & .044 \\
Audit fees & .117 & .356 & .091 & .328 & .747 \\
Consultancy & -1.344 & 1.235 & -.228 & -1.088 & .290 \\
audit committee & .107 & .246 & .127 & .434 & .045 \\
Audit independence & 0.714 & .504 & 0.419 & -1.416 & .173 \\
Board size & .512 & .325 & .320 & 1.574 & .132 \\
\hline
\end{tabular}

a. Dependent variable Audit Quality

Table 4.8 represents the regression coefficients which indicate the gradient of both the standardized and unstandardized coefficients of the tested variables. The above indicated standardized coefficients for the variables; audit firm rotation had a beta coefficient of 0.087 , and audit fees had a beta coefficient of 0.117 , consultancy -1.344 , audit committee 0.107 , and audit independence 0.714. In contrast, board size had a beta coefficient of 0.512. From these coefficient variables indicated, the equation can be deduced as follows:

$$
\begin{array}{r}
A Q=5.779+0.087 X_{1}+0.117 X_{2}+(-1.344) X_{3}+ \\
0.107 X_{4}+0.714 X_{5}+ \\
+0 . Q=5.779+0.087 X \_1+0.117 X_{-} 2+-1.344 X_{-} \_3+0.107 X_{-} \\
4+0.714 X \_5++0.512 X_{6}+\varepsilon
\end{array}
$$

The above equation results show that audit firm rotation leads to a 0.087 increase in $\mathrm{AQ}$, considering all other factors are held constant. Thus $H_{0}$ rejected and $H_{1}$ accepted, meaning that the variable audit firm rotation has a significant effect on audit quality. More so, as shown by 0.117 , the results reveal that an adjustment by 0.117 in audit fees lead to an increase in the AQ, ceteris paribus. Furthermore, the model points out that a unit changes in consultancy services provided by -1.344 upturns in the AQ would be realized ceteris paribus. An increase in audit committee by 0.107 leads to a proportionate increase in AQ while a change in audit independence by 0.714 lead to a change with the same rate on audit quality. Lastly, a change by 0.512 board size causes a 0.512 change in audit quality. This means that the consultancy services insignificantly affect AQ that, the more the services increases poor AQ is realized. The regression test revealed that four variables were significant since they had a positive Beta coefficient with board size having the greatest effect, followed by audit firm rotation, audit fees, audit independence and consultancy having least score insignificant on audit quality.

\subsection{Discussion of Regression Findings}

As the first objective of the study was to determine and establish the relationship surrounding audit firm rotation and AQ in relation to stakeholder perceptive, the study used correlation tests, descriptive statistics, and linear regression analysis. The linear regression analysis was a substantive ideal for analyzing the data since it showed the extent to which audit firm rotation and other factors significantly influence the factor included in the model summary, ANOVA table, and the regression coefficients. Regression analysis test results endeavour to determine how audit firm rotation as the independent variable relates to $\mathrm{AQ}$ being a dependent variable. The adjusted $R^{2}$ was 0.324 or $32.4 \%$ (table 4.6), which indicated the dependent variable's variance for an increase in the independent variables. This value was low, indicating that other variables cause the other $67.6 \%$ of the variance in $\mathrm{AQ}$, which is supported by interview responses by another manager who noticed that AQ is a broad concept and has many factors that influence it. The study's ANOVA test indicated an $F$ value of 1.548 and a p-value of 0.041 (See table 4.7). This indicated that the independent variables are significant in terms of goodness of fit since the $p$-value of 0.031 is far less than the significant 0.05 .

The coefficients table provided the various beta coefficients indicating how the independent variables affected audit quality. The first independent variable was audit rotation with a coefficient of 0.047 and a $t$-value of 0.278 (table 4.8). The significance value of 0.047 is smaller than 0.05 (confidence level) as subject to the test, meaning it is significant to AQdue to the extent to which it influences the dependent variable. Table 4.8 shows that, though Rotation is positively related to audit quality, the effect is low. The result provides minimal support for the direct relationship posited in the second hypothesis $\left(H_{1}\right)$. The regression results were against that of Ruiz-Barbadillo, Gómez-Aguilar, De Fuentes-Barberá \& García-Benau (2000) who concluded that MAFR is not a fitting mechanism for improving auditor quality through enhancing audit independence. Moreover, the study done by [16] supports these findings as they assert that MAFR is essential after using multilinear regression analysis. The second variable used for analysis was audit fees which had a standardized beta of 0.091 , a $t$-value of 0.328 and a significance value of 0.747 (table 4.8) indicating that it was not a significant factor affecting audit quality. This was because the p-value, 0.747 , was greater than the 
significance value of 0.05 . The study was not consistent with Arruñada and Paz (1997) and other studies which indicated that AQ increased with audit fees.

Provision of consultancy services had a standardized coefficient of -0.228 , a t-value of 1.088 (table 4.8), and a significant value of 0.290 , indicating an insignificant factor to audit quality. Consultancy service was not rated since it was a nominal value while the others were ordinal. Therefore, as an auditor continuously provides consultancy services, this might lead to deteriorating audit quality. This goes against Wooten's [53] finding who argued that providing additional services allowed auditors to understand the client and its business processes more. Audit committee had a positive value of 0.127 , meaning it increases AQ by $12.7 \%$, despite the supported by the $\mathrm{p}$-value of 0.045 , which was below the 0.05 significance level. These results agree with [2], where they established that audit committee characteristics influence the company's reporting capability. More so, audit independence had a 0.714 positive connection with audit quality. Therefore, it gives assurance in the quality of the audit. This implies that acting free from influence may make management not hide information to frustrate the auditors. Audit independence increases the level of accuracy. Therefore, the chances that audit results would be true and fair will be high. This is inconsistent with the assertions by [35] \& [36]. Their results showed that audit independence is a crucial element considered with caution to improve the AQ. Lastly, board size had a beta coefficient of 0.320 based on standardized data, signifying a positive relation with audit quality. The size of the board influences the extent to which debates as well as make policies. These findings are consistent with those by [32] in which they found that board composition has a significant positive influence on the AQ report produced by the auditor.

\section{Conclusion and Recommendation of the Study}

The study concluded that rotation of audit firm influences the quality of audit for listed firms as well as the private sector in Zimbabwe positively as it increased auditor independence and brings a fresh perspective to the audit and reduce economic dependence within the audit market. We also concluded that audit tenure impairs auditors' ability to produce quality work as time increases which means switching is necessary. Part of the study conclusion is that audit firm rotation should be regulated in Zimbabwe, and that other factors that influence audit quality positively include audit fees, audit committee, audit independence and board size. In contrast, consultancy services are negatively correlated to the quality of audit work, which means it continues to increase, which can negatively influence audit quality. The study recommends firms to switch auditors to build stakeholder trust by increasing auditor independence and bringing new ideas. Besides rotating, auditors companies must pay audit fees comparable to the level of audit services provided to attract a quality service. Furthermore, audit committee characteristics such as level of education, consistency of meetings, and audit committee rotation to members reduce financial misreporting.

\section{Conflict of Interest}

There is no conflict of interest on this study as any source does not fund it.

\section{REFERENCES}

[1] A. Abdul Rahman, M.D. Hamdan. The extent of compliance with FRS 101 standard: Malaysian evidence, Journal of Applied Accounting Research, Vol. 18, No1, pp. 87-115, 2017.

[2] H. Al-Khaddash, R. Al Nawas, A. Ramadan. Factors affecting the quality of auditing: The case of Jordanian commercial banks, International Journal of Business and Social Science, Vol. 4, No. 11, 2013.

[3] B. Arel, R. Brody, K. Pany. Findings on the effects of audit firm rotation on the audit process under varying strengths of corporate governance, Advances in Accounting, Vol. 22, pp. $1-27,2006$.

[4] O.S. Azeita, A.O. Austin, E.C. Imuentinyan. Share Prices, Insider Dealings and Creative Accounting Practices: The Nigerian Listed Non-Financial Services Companies in Perspective, International Journal of Governance and Development, Vol. 6, No. 1, pp. 90-95, 2019.

[5] A.T. Babatolu, O.O. Aigienohuwa, E. Uniamikogbo. Auditor's Independence and Audit Quality: A Study of Selected Deposit Money Banks in Nigeria, International Journal of Finance and Accounting, Vol. 5, No. 1, pp. 13-21, 2016. DOI: $10.5923 /$ j.ijfa.20160501.02.

[6] M. Cameran. Auditing in Italy: The development of a highly-regulated setting before and after the Parmalat case, Auditing,Trust and Governance, pp. 162-185, 2015: Routledge.

[7] M. Cameran, A. Ditillo, A. Pettinicchio. Audit team attributes matter: How diversity affects audit quality," European Accounting Review, Vol. 27, No.4, pp. 595-621, 2018.

[8] M. Cameran, A. Prencipe, M. Trombetta. Auditor tenure and auditor change: does mandatory auditor rotation improve audit quality? Paper presented at the American Accounting Association 2009 Annual Congress: Accounting at a tipping point, 2009.

[9] W. Chi, H. Huang, Y. Liao, H. Xie. Mandatory audit partner rotation, audit quality, and market perception: Evidence from Taiwan, Contemporary Accounting Research, Vol. 26, No.2, pp. 359-391, 2009. 
[10] J. Choi, H. Lim, D. Mali. Mandatory audit firm rotation and Big4 effect on audit quality: evidence from South Korea, Asian Academy of Management Journal of Accounting and Finance, Vol. 13, No. 1, pp. 1-40, 2017.

[11] L.R. Davis, B. Soo, G. Trompeter. Audit tenure, auditor's independence and earnings management, Working Paper, Boston College, 2003.

[12] L.E. DeAngelo. Auditor independence, 'low balling', and disclosure regulation, Journal of accounting and Economics, Vol. 3, No. 2, pp. 113-127, 1981.

[13] M.N. El Guindy, M.A.K. Basuony. Audit Firm Tenure And Earnings Management: The Impact of Changing Accounting Standards In UK Firms, The Journal of Developing Areas, Vol. 52, No. 4, pp. 167-181, 2018.

[14] A. Georgiou. Auditors'perceptions On Impact Of Mandatory Audit Firm Rotation On Auditor Independence-Evidence From Cyprus, Science and Business: Development Ways, Vol. 3, No. 81, pp. 149-156, 2018.

[15] S.K. Gates, D.J. Lowe, P.M.J. Reckers. Restoring public confidence in capital markets through auditor rotation, Managerial Auditing Journal, Vol. 22, pp. 5-18, 2007.

[16] K. Gwizu, G. Waeni, D. Chimanga, E. Saidi, N. Karasa. T. Mwero, D. Muzvividzi. Mandatory Audit Firm Rotation and Audit Quality in Zimbabwe, Research Journal of Finance and Accounting, Vol. 8, No. 6, 2017.

[17] K. Harris, S. Whisenant. Mandatory audit rotation: an international investigation, University of Houston.

[18] R. Hoitash, A. Markelevich, C.A. Barragato. Auditor fees and audit quality, Managerial Auditing Journal, Vol. 22 No. 8, pp. 761-786, 2012, 2007.

[19] R. Hussey, G. Lan. An examination of auditor independence issues from the perspectives of U.K. finance directors, Journal of Business Ethics, Vol. 32, pp. 169-178, 2001.

[20] M.C. Jensen, W.H Meckling. Theory of the firm: Managerial behaviour, agency costs and ownership structure, Journal of financial economics, Vol. 3, No.4, pp. 305-360, 1976.

[21] D. Khudhair, F. Al-Zubaidi, A. Raji. The effect of board characteristics and audit committee characteristics on audit quality, Management Science Letters, Vol. 9, No. 2, pp. 271-282, 2019.

[22] S.M., Kim, S.M. Kim, D.H. Lee, S.W. Yoo. How Investors Perceive Mandatory Audit Firm Rotation in Korea, Sustainability,Vol. 11, No.4, pp. 1089, 2019.

[23] Kimball International, Inc. "PCAOB Rulemaking Docket Matter No. 37," 2011. accessed 10/8/2012.

[24] B. Klein, K. Leffler. The role of market forces in assuring contractual performance. Journal of Political Economy, Vol. 89: pp. 615-641, 1981.

[25] G.V. Krishnan, J. Zhang. Do Investors Perceive a Change in Audit Quality Following the Rotation of the Engagement Partner? A Journal of Practice \& Theory, Vol. 30, No.3, pp. 59-79, 2018. https://doi.org/10.2308/ajpt-10048.

[26] T. Law. Combining qualitative and quantitative approaches: Some arguments for mixed methods research, Scandinavian Journal of Educational Research, Vol. 56, No.2, pp. 155-165,

\section{2. doi: 10.1080/00313831.2011.568674}

[27] P. Lawrence. Effect of mandatory audit firm rotation on client disclosure quality: Evidence from Europe, Erasmus University Master Thesis, 2017.

[28] A.L. Mayse. Lenders' Reactions to Audit Rotation for Nonpublic Companies, Journal of Leadership, Accountability and Ethics, Vol. 15, No. 3, pp. 95-108, 2018.

[29] M.D. Meckfessel, D. Sellers. The impact of Big 4 consulting on audit reporting lag and restatements, Managerial Auditing Journal, Vol. 32, No. 1, 19-49, 2017. https://doi.org/10.1108/MAJ-02-2016-1321.

[30] A.S. Mustafa, A. Che Ahmad, S. Chandren. Board diversity and audit quality: evidence from Turkey, Journal of Advanced Research in Business and Management Studies, Vol. 6, No. 1, pp. 50-60, 2017.

[31] M. Moody, K.J. Pany, P.M.J. Reckers. Strong corporate governance and audit firm rotation:Effects on judges' litigation judgments, Accounting Horizons, Vol. 20, pp. 253-270, 2006.

[32] A.S. Mustafa, A. Che-Ahmad, S. Chandren. Board diversity, audit committee characteristics and audit quality: The moderating role of the control-ownership wedge, Business and Economic Horizons, 14(3), 587-614, 2018.

[33] J.N. Myers, L.A. Myers, C.T. Omer. Exploring the term of the auditor-client relationship and the quality of earnings: A case of mandatory audit rotation? The Accounting Review, Vol. 78, No. 3, pp. 779-799, 2003.

[34] S.N. Narges, O. Faraji, M. Ezadpour, C.Z. Joudaki. CEO Over-confidence and Corporate Cash Holdings: Emphasizing the Moderating Role of Audit Quality, Journal of Accounting and Auditing Review, Vol. 25, No. 2, pp. 199-214, 2018

[35] A.N. Ndubuisi, M.N. Okeke, O. J. Chinyere. Audit Quality Determinants: Evidence from Quoted Health Care Firms in Nigeria, International Journal of Academic Research in Accounting, Finance and Management Sciences, Vol. 7, No. 4, pp. 216-231, 2017,

[36] G.S. Ningrum, L.K. Wedari. Impact of Auditor's Work Experience, Independence, Objectivity, Integrity, Competency and Accountability on Audit Quality, Journal Economics \& Business Atmajaya Indonesia, Vol. 1, No. 1, pp. 19-33, 2017.

[37] A.O. Okolie. Accrual - Based earnings Management, Corporate Policies and Managerial Decisions of Quoted Companies in Nigeria, Research Journal of Finance and Accounting, Vol. 5, No. 2, pp. 1-14, 2014.

[38] C. O'Leary, R. Radich. Audit firm rotation and independence: Australian evidence, Accountability and Performance, Vol. 2, No. 3, pp. 37-58, 1996.

[39]R.M. Orin. Ethical guidance and constraint underthe Sarbanes-Oxley Act of 2002, Journal of Accounting, Auditing \& Finance, Vol. 23, No. 1, pp. 141-171, 2008.

[40] A.O. Otekunrin, D.G. Fagboro, T.I. Nwanji, F.F. Asamu, O.B. Ajiboye, J.A. Falaye. Performance of deposit money banks and liquidity management in Nigeria, Banks and Bank Systems, Vol.14, No.3, pp.152-161, 2019. DOI: http://dx.doi.org/10.21511/bbs.14(3).2019.13. 
[41] A.O. Otekunrin, T.I. Nwanji, B.O. Obasaju. Capital Structure and Profitability of Selected Agriculture and Agro-Allied Firms on Nigerian Stock Exchange: Post International Financial Reporting Standard Analysis, International Journal of Civil Engineering and Technology, Vol. 9, No. 12, pp. 1615-1625, 2018.

[42] A.O. Otekunrin, J.K. Olowookere, D.Z. Agba, S.A. Fakile, D.F. Eluyela, B.O. Ajiboye, I.J. Adama. Capital Structure and its determinants: Case of quoted firms in Agriculture and agro-allied sector of the Nigerian economy, Journal of Engineering and Applied Sciences, Vol. 14, No.24, pp. 9667-9676, 2019.

[43] A.J. Otieno. The Relationship Between Auditor Rotation and Audit Quality of Commercial Banks in Kenya, Master Degree Thesis, University of Nairobi, 2014.

[44] B. Pamungkas, R. Ibtida, C. Avrian, Factors influencing audit opinion of the Indonesian municipal governments' financial statements. Cogent Business \& Management, Vol. 5, No. 1, pp. 1-18, 2018.

[45] M. Ravindran, S. Nagarajah, S. Ananthasayanan. Audit Committee Attributes and Share Price Evidence from Banking and Finance Companies Listed on the Colombo Stock Exchange, 15th International Conference on Business Management, University of Sri Jayewardenepura, pp. 56-71, 2018. http://dr.lib.sjp.ac.lk/handle/123456789/8150

[46] A. Rudyanto, D. Daniswari, Y. Oktaviani. Audit Firm Reputation versus Auditor Capability: Their Effect on Audit Quality in Indonesia," Accounting and Finance Review, Vol. 2, No.4, pp. 12 - 20, 2017.

[47] H. Sayyar, R. Basiruddin, S.A. Rasid, M.A. Elhabib. The impact of audit quality on firm performance: Evidence from
Malaysia, Journal of Advanced Review on Scientific Research, Vol. 10, No. 1, pp, 1-19, 2015.

[48] S.V. Siregar, F. Amarullah, A. Wibowo, V. Anggraita, Audit tenure, auditor rotation, and audit quality: the case of Indonesia, Asian Journal of Business and Accounting, Vol. 5, No.1, pp. 55-74. 2012.

[49] A...Stringer, Jury still out on audit firm rotation' posted at Institute of Chartered Accountants, 2012, Australia, <https://www.charteredaccountants.com.au/secure /mycommunity/blogs/astringer/ Number\%20one\%20in\%20 Numbers $\% 20 \mathrm{blog} / 241 /$ jury-still-out-on-audit-firm-rotation>

[50] The Institute of Chartered Accountants of Zimbabwe (ICAZ). Revision of the Zimbabwe Stock Exchange Requirements, IFRS Update Seminar, 31 October 2013.

[51] K. Tysiac. Mandatory audit firm rotation rules published in EU, Journal of Accountancy, 2014.

[52] P. Velte, T. Loy. The impact of auditor rotation, audit firm rotation and non-audit services on earnings quality, audit quality and investor perceptions: A literature review Journal of Governance and Regulation, Vol. 7, No.2, 2018.

[53] A.B. Wilson, C. McNellis, C.K. Latham. Audit firm tenure, auditor familiarity, and trust: Effect on auditee whistleblowing reporting intentions, International Journal of Auditing, Vol. 22, No.2, pp. 113-130, 2018.

[54] T.C. Wooten. Research about audit quality, CPA Journal, Vol. 73, pp. 48-51, 2003.

[55] R. Yuniarti. Audit firm size, audit fee and audit quality, Journal of Global Management,.Vol. 2, No. 1, pp. 84-97, 2011. 